\title{
Pengaruh Financial Attitude, Financial Knowledge, Dan Financial Behavior Terhadap Financial Technology Literacy
}

\author{
Jefrie dan Hendra Wiyanto \\ Program Studi Manajemen, Fakultas Ekonomi dan Bisnis \\ Universitas Tarumanagara, Jakarta \\ Email:jeffriejefrie@gmail.com
}

\begin{abstract}
The purpose of this research is to analyze the effect of Financial Attitude, Financial Knowledge, and Financial Behavior toward Financial Technology Literacy. The sample of this research were Go-Pay users in West Jakarta. The sample was selected using a non-probability sampling method amounted to 250 respondents by distributing questionnaire via online through the Google form section. The data analysis technique used is structural equation modeling that helped by Smart-PLS version 3.0 program. The results of this research reveals that Financial Attitude, Financial Knowledge, and Financial Behavior have effects towards Financial Technology Literacy on Go-Pay users in West Jakarta.
\end{abstract}

Keywords: Financial Attitude, Financial Knowledge, Financial Behavior, Financial Technology Literacy

Abstrak: Tujuan dari penelitian ini adalah untuk menguji pengaruh Financial Attitude, Financial Knowledge, dan Financial Behavior terhadap Financial Technology Literacy. Sampel pada penelitian ini adalah pengguna Go-Pay di Jakarta Barat. Sampel dipilih dengan menggunakan metode non probability sampling yang berjumlah sebanyak 250 responden dengan menyebarkan kuesioner secara online dengan bantuan Google form. Teknik analisis data yang digunakan adalah structural equation modeling yang dibantu dengan bantuan program Smart-PLS versi 3.0. Hasil yang didapat pada penelitian ini menunjukkan bahwa terdapat pengaruh Financial Attitude, Financial Knowledge, dan Financial Behavior terhadap Financial Technology Literacy pada pengguna Go-Pay di Jakarta Barat.

Kata kunci: Sikap Finansial, Pengetahuan Finansial, Tingkah Laku Finansial, Literasi Teknologi Finansial

\section{LATAR BELAKANG}

Teknologi merupakan salah satu alat untuk mempermudah kegiatan masyarakat dalam memanfaatkan sumber daya yang dibutuhkan sehingga menjadi lebih mudah dan efisien. Menurut De Bassa Scheresberg (2013) orang-orang yang memiliki tingkat pengetahuan teknologi finansial (financial technology literacy) yang lebih tinggi akan membuat dirinya menjadi lebih percaya diri dalam membuat keputusan secara pribadi atau individual.

Secara implisit bahwa teknologi keuangan (fintech) memiliki fleksibilitas yang memungkinkan teknologi berbasis layanan keuangan ini untuk menawarkan berbagai layanan mulai dari pembayaran, investasi, hingga infrastruktur pendukung (Riemer et al., 2017). Ini adalah salah satu pola dasar dari fluktuasi dalam kehidupan manusia di era 
digitalisasi saat ini. Mereka yang bertahan adalah mereka yang dapat mengikuti arus globalisasi dan dapat menjaga arah kemajuan teknologi saat ini (Aritonang \& Arisman, 2017).

Dalam penelitian ini, peneliti lebih berfokus untuk mendalami faktor-faktor internal yang mempengaruhi financial technology literacy dengan alasan bahwa faktor eksternal memiliki cakupan yang lebih luas sehingga berada di luar kontrol keuangan. Beberapa faktor internal yang akan di bahas antara lain financial attitude, financial knowledge, dan financial behaviour.

Financial attitude atau sikap keuangan mengacu pada sikap umum terhdadap keuangan. Perilaku dan kebiasaan finansial individu mungkin sangat bervariasi baik dalam ruang dan waktu, karena perumusan dan modifikasi ini dipengaruhi oleh sejumlah faktor (Nemeth et al., 2016).

Financial knowledge atau pengetahuan keuangan yang terbatas atau kurangnya kecanggihan finansial dapat mempegaruhi partisipasi individu dalam komitmennya membangun ekonomi digital (Rhine \& Toussaint-Comeau, 2002).

Financial behaviour atau perilaku keuangan ini dapat mendorong seseorang individu untuk merencanakan pengeluaran dan membangun jaringan pengaman keuangan. Perilaku dan kebiasaan finansial individu mungkin sangat bervariasi baik dalam ruang dan waktu, karena perumusan dan modifikasi ini dipengaruhi oleh sejumlah faktor (Nemeth et al., 2016).

Financial technology literacy atau literasi teknologi keuangan merupakan kombinasi dari ketrampilan, pengetahuan, sikap dan perilaku yang diperlukan untuk membuat keputusan keuangan yang sehat dan pada akhirnya tercapai sebuah kesejahteraan finansial di masing-masing individu (Atkinson \& Messy, 2012).

Melihat permasalahan di atas, dapat disimpulkan bahwa tujuan dari penelitian ini untuk mengetahui apakah financial attitude, financial knowledge, dan financial behavior terdapat pengaruh terhadap financial technology literacy pada pengguna Go-Pay di Jakarta Barat.

\section{KAJIAN TEORI}

Penelitian ini mengacu pada Technology Acceptance Model (TAM) Theory (Davis, Bagozzi \& Warshaw, 1989) menjelaskan model penelitian yang telah dikembangkan untuk menentukan tingkat penerimaan teknologi baru di kalangan masyarakat luas. Menurut Muntianah, Astuti \& Azizah (2012) menemukan bahwa TAM dikenal dapat mempengaruhi pengguna dalam menggunakan sebuah teknologi baru yang dilihat dari beberapa faktor seperti minat sikap (attitude intention), minat perilaku (behavior intention), pengetahuan minat (knowledge intention), dan penggunaan sistem (actual system usage).

Financial technology literacy merupakan kemampuan seseorang untuk mengetahui, menganalisis, mengelola, dan menginformasikan tentang kondisi keuangan yang mempengaruhi kesejahteraan material individu terkait penerimaan teknologi baru di era digitalisasi (Anthes, 2004). 
Financial Atttiude merupakan kemampuan seseorang dalam merencanakan dan menghemat uang di masa depan sehingga tidak menjadi sumber kecemasan atau rasa takut terhadap uang (Atkinson \& Messy, 2012).

Financial knowledge merupakan elemen paling umum dari banyak definisi konseptual tentang literasi keuangan dimana literasi keuangan didefinisikan sebagai pengetahuan keuangan (Hilgert, 2003). Financial knowledge dinyatakan secara statistik terkait dengan praktik keuangan karena seorang individu yang tahu lebih banyak akan lebih mungkin untuk terlibat dalam praktik keuangan (Hogarth \& Beverley, 2003).

Financial Behavior merupakan penentuan, akuisisi, alokasi, dan pemanfaatan sumber daya keuangan dimana perilaku keuangan ini dianggap sebagai salah satu konsep utama pada literasi keuangan (Horne \& Wachowicz, 2002).

Kaitan antara financial attitude dan financial technology literacy. Munculnya layanan pembayaran berbasis teknologi telah mengubah kemampuan seorang individu dalam merencanakan keuangan di masa depan pada pengaruh teknologi baru di era digitalisasi (Bhushan \& Medury, 2014). Semakin tinggi literasi keuangan individu terhadap pengaruh teknologi maka seharusnya pengembangan sikap keuangan antar generasi akan lebih berfokus pada program pendidikan keuangan dalam upaya mencapai kesejahteraan finansial di era digitalisasi (Ibrahim \& Alqaydi, 2013).

Kaitan antara financial knowledge dan financial technology literacy. Sanderson (2015) percaya bahwa financial knowledge akan menciptakan pengetahuan dan ketrampilan seorang individu dalam mengambil sebuah keputusan keuangan yang tepat guna mencapai manajemen sumber daya teknologi keuangan yang efektif. Untuk meningkatkan kesadaran financial knowledge maka program pendidikan teknologi keuangan perlu disosialisasikan agar tidak menimbulkan persepsi risiko dalam menggunakan teknologi secara cerdas dan akurat (Maassen Van Den Brink \& Wilschut, 2018).

Kaitan antara financial behavior dan financial technology literacy. Kalekye \& Memba (2015) mengatakan perilaku perencanaan keuangan, perilaku investasi, perilaku pembayaran tagihan, perilaku tabungan, perilaku kartu kredit dan perilaku anggaran merupakan tingkat literasi teknologi keuangan pada kaum milenial. Financial behavior yang dimaksud seperti perilaku seorang individu yang berkaitan dengan pengambilan keputusan keuangan dalam menggunakan aplikasi pembayaran berbasis teknologi (payment) dimana mereka harus bisa mengendalikan program anggaran yang tepat dan medorong sifat menabung (Bhushan \& Medury, 2014).

Kerangka pemikiran dalam penelitian ini adalah sebagai berikut : 


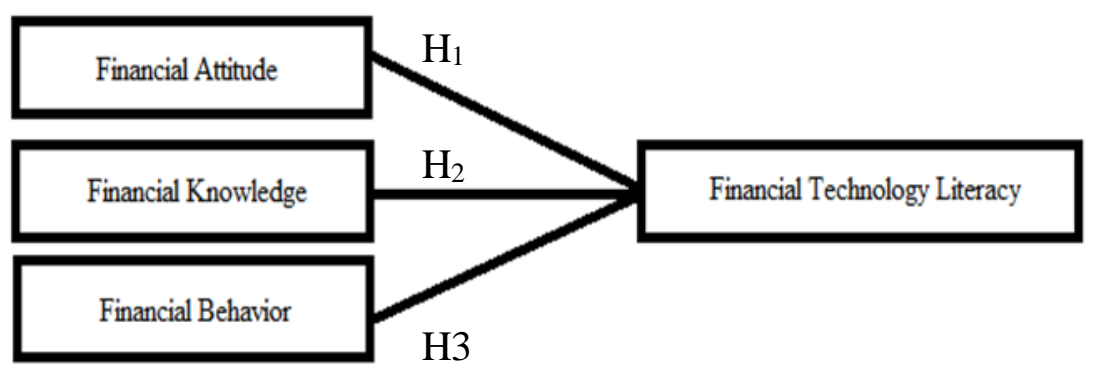

Dari kerangka penelitian di atas, maka terbentuklah sebuah hipotesis yang akan diuji dalam masalah ini adalah :

$\mathrm{H}_{1}$ : Financial Attitude (FA) berpengaruh terhadap Financial Technology Literacy.

$\mathrm{H}_{2}$ : Financial Knowledge (FK) berpengaruh terhadap Financial Technology Literacy.

$\mathrm{H}_{3}$ : Financial Behavior (FB) berpengaruh terhadap Financial Technology Literacy.

\section{METODOLOGI}

Penelitian ini menggunakan desain penelitian deskriptif dengan metode kuantitatif. Populasi dalam penelitian ini adalah seluruh pengguna Go-Pay yang berada di Jakarta Barat. Metode pengambilan sampel yang digunakan dalam penelitian ini adalah non probability sampling dengan teknik purposive sampling. Alasan digunakannya teknik purposive sampling karena terdapat kriteria tertentu yang harus dipenuhi dalam penelitian ini.

Dalam penelitian ini melibatkan 274 responden namun beberapa dari jumlah responden ada yang tidak memenuhi kriteria yang telah ditentukan dalam screening question pada kuesioner, maka responden yang dapat digunakan dalam penelitian ini sebanyak 250 responden. Data penelitian ini dikumpulkan dengan menggunakan kuesioner yang disebarkan secara online melalui Google form. Skala yang digunakan untuk mengukur setiap indikator pada variabel dalam penelitian ini yaitu menggunakan skala interval dalam bentuk skala likert lima poin dengan 1 menunjukkan "Sangat Tidak Setuju" dan 5 menunjukkan "Sangat Setuju".

Pada penelitian ini menggunakan model Structural Equation Modeling (SEM), dimana dalam model ini terdiri dari 2 model analisis yaitu outer model analysis yang terdiri dari uji validitas dan uji reliabilitas dan inner model analysis yang terdiri dari uji koefisien determinasi $\left(\mathrm{R}^{2}\right)$, uji goodness fit test, dan uji hipotesis.

\section{HASIL ANALISIS DATA}

Subjek penelitian ini adalah pengguna pembayaran berbasis teknologi Go-Pay di Jakarta Barat. Responden ini dikelompokkan berdasarkan domisili, jenis kelamin, usia, pekerjaan, pendidikan terakhir, dan periode penggunaan Go-Pay. Berdasarkan domisili, didapatkan bahwa 250 orang $(91,2 \%)$ menjawab ya berdomisili di Jakarta Barat dan sisanya sebesar 24 orang $(8,8 \%)$ menjawab tidak berdomisli di Jakarta Barat. Berdasarkan jenis kelamin, didapatkan bahwa sebesar 144 orang $(52,6 \%)$ berjenis kelamin pria dan sebesar 130 orang $(47,4 \%)$ berjenis kelamin wanita. Berdasarkan usia, didapatkan bahwa responden yang 
berusia 18-25 tahun sebanyak 251 orang (91,6\%), 26-35 tahun sebanyak 19 orang $(6,9 \%)$, 36-45 tahun sebanyak 3 orang (1.1\%), dan diatas 45 tahun sebanyak 1 orang $(0,4 \%)$. Berdasarkan pekerjaan, didapatkan bahwa responden sebagai mahasiswa sebanyak 222 orang $(81 \%)$, sebagai karyawan swasta atau negeri sebanyak 42 orang $(15,3 \%)$, sebagai wirausaha sebanyak 8 orang $(2,9 \%)$, sebagai pekerja lepas sebanyak 1 orang $(0,4 \%)$, dan sebagai paruh waktu (part-time) sebanyak 1 orang $(0,4 \%)$. Berdasarkan pendidikan terakhir, didapatkan bahwa sebanyak 208 orang $(75,9 \%)$ berpendidikan terakhir di bangku SMA. Selanjutnya, sebesar 64 orang $(23,4 \%)$ berpendidikan terakhir D3/S1 dan sisanya sebesar 2 orang $(0,7 \%)$ berpendidikan terakhir S2. Berdasarkan periode penggunaan Go-Pay, didapatkan bahwa sebanyak 168 orang $(61,3 \%)$ sudah menggunakan Go-Pay selama lebih dari 12 bulan., sebanyak 42 orang $(15,3 \%)$ sudah menggunakan Go-Pay kurang lebih 6 sampai dengan 12 bulan dan sisanya sebanyak 64 orang $(23,4 \%)$ sudah menggunakan GoPay selama kurang lebih 1 sampai dengan 5 bulan. Dari total 250 responden yang digunakan dapat diindikasikan bahwa sampel yang digunakan yaitu valid dan reliable. Hal ini dapat dilihat dari hasil analisis Average Variance Extracted (AVE) dari setiap variabel yang diteliti menunjukkan nilai koefisien lebih besar dari 0,5.

Tabel 1. Hasil Average Variance Extracted (AVE)

\begin{tabular}{|c|c|}
\hline Variabel & AVE \\
\hline Financial Technology Literacy & $\mathbf{0 , 6 3 5}$ \\
\hline Financial Attitude & $\mathbf{0 , 6 3 4}$ \\
\hline Financial Knowledge & $\mathbf{0 , 5 7 7}$ \\
\hline Financial Behavior & $\mathbf{0 , 6 8 8}$ \\
\hline
\end{tabular}

Tabel 2. dan gambar 1. menunjukkan nilai uji cross loading masing-masing indikator pada tiap variabel yang diteliti. Nilai cross loading yang didapat menunjukan nilai di atas 0,7 yang artinya memenuhi kriteria dari convergent validity.

Tabel 2. Hasil Uji Cross Loading

\begin{tabular}{|l|c|c|c|c|}
\hline & $\begin{array}{c}\text { FINANCIAL } \\
\text { ATTITUDE }\end{array}$ & $\begin{array}{c}\text { FINANCIAL } \\
\text { BEHAVIOR }\end{array}$ & $\begin{array}{c}\text { FINANCIAL } \\
\text { KNOWLEDGE }\end{array}$ & $\begin{array}{c}\text { FINANCIAL } \\
\text { TECHNOLOGY } \\
\text { LITERACY }\end{array}$ \\
\hline FA1 & 0,744 & 0,241 & 0,328 & 0,368 \\
\hline FA2 & 0,785 & 0,248 & 0,372 & 0,428 \\
\hline FA3 & 0,855 & 0,342 & 0,372 & 0,445 \\
\hline FB1 & 0,224 & 0,856 & 0,643 & 0,448 \\
\hline FB2 & 0,322 & 0,790 & 0,508 & 0,438 \\
\hline FB3 & 0,325 & 0,841 & 0,496 & 0,490 \\
\hline FK1 & 0,414 & 0,373 & 0,708 & 0,336 \\
\hline FK2 & 0,296 & 0,442 & 0,781 & 0,423 \\
\hline FK3 & 0,379 & 0,546 & 0,811 & 0,470 \\
\hline FK4 & 0,294 & 0,618 & 0,733 & 0,430 \\
\hline
\end{tabular}


Jefrie dan Wiyanto: Pengaruh Financial Attitude, Financial Knowledge, Dan Financial...

\begin{tabular}{|l|l|l|l|l|}
\hline FTL1 & 0,559 & 0,407 & 0,437 & 0,826 \\
\hline FTL2 & 0,377 & 0,492 & 0,449 & 0,818 \\
\hline FTL3 & 0,287 & 0,432 & 0,437 & 0,745 \\
\hline
\end{tabular}

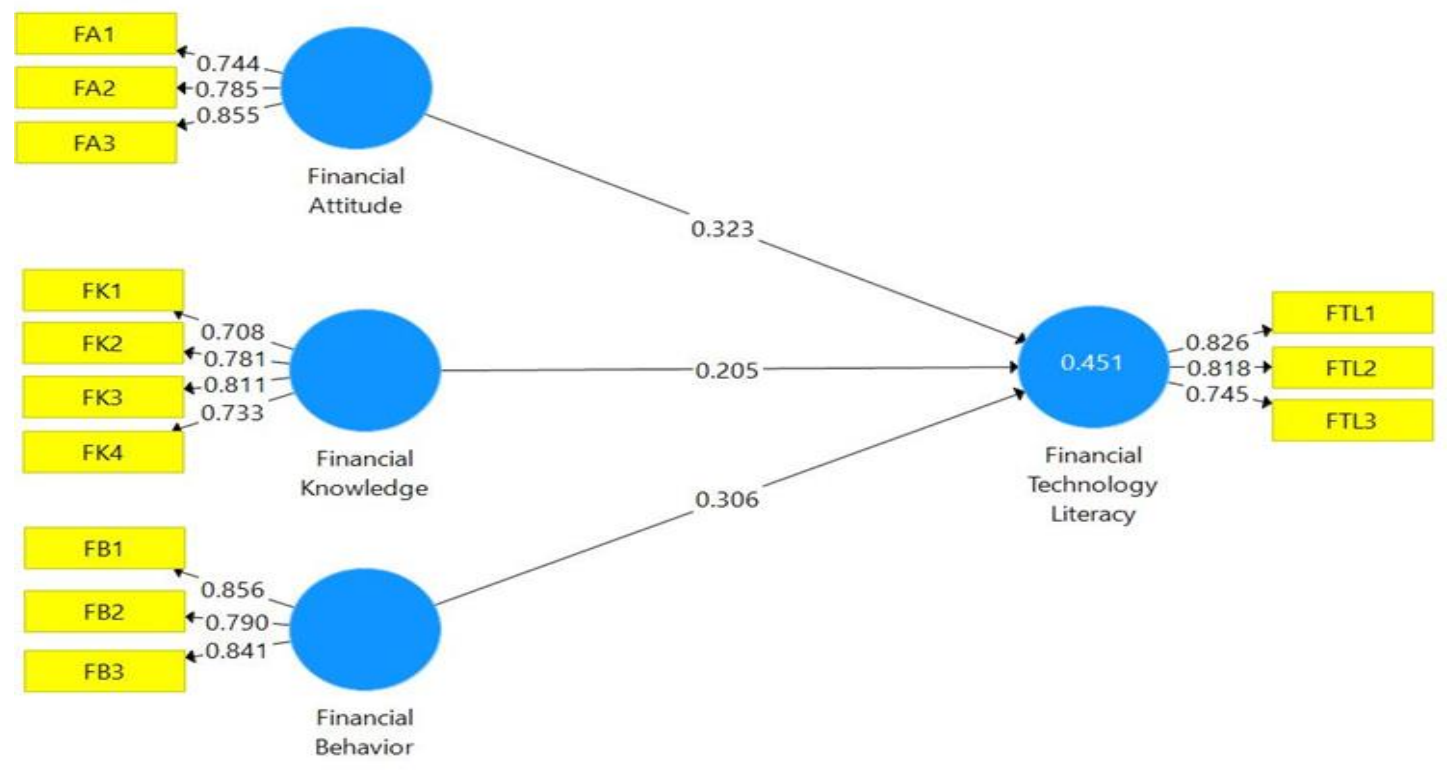

Gambar 1. Hasil Convergent Validity

Tabel 2. menunjukkan nilai cross loading masing-masing indikator yang diteliti pada penelitian ini. Nilai cross loading masing-masing indikator menunjukan nilai yang lebih tinggi daripada nilai cross loading indikator tersebut dalam konstruk lainnya. Maka kriteria dari convergent validity dengan pendekatan nilai cross loading terpenuhi.

Tabel 3. Hasil Analisis Reliabilitas

\begin{tabular}{|l|l|l|l|}
\hline Variabel & $\begin{array}{l}\text { Cronbach's } \\
\text { Alpha }\end{array}$ & rho_A & $\begin{array}{l}\text { Composite } \\
\text { Realibility }\end{array}$ \\
\hline FINANCIAL ATTITUDE & 0,710 & 0,719 & 0,838 \\
\hline FINANCIAL BEHAVIOR & 0,773 & 0,776 & 0,869 \\
\hline FINANCIAL KNOWLEDGE & 0,756 & 0,764 & 0,845 \\
\hline $\begin{array}{l}\text { FINANCIAL } \\
\text { TECHNOLOGY LITERACY }\end{array}$ & 0,713 & 0,723 & 0,839 \\
\hline
\end{tabular}

Tabel 3. di atas menunjukan nilai cronbach's alpha dan composite reliability masing-masing variabel yang diteliti memiliki nilai lebih besar dari 0,6. Maka variabel-variabel yang diteliti pada penelitian ini dapat dinyatakan reliabel. Koefisien determinasi adalah ukuran dari akurasi prediksi sebuah model. Koefisien determinasi mewakili efek gabungan variabel 
eksogen pada variabel endogen, dengan kata lain koefisien determinasi bertujuan untuk melihat kontribusi variabel eksogen untuk memprediksi variabel endogen. Hasil koefisien determinasi ( $R$-square) akan ditampilkan pada tabel 4. berikut ini.

Tabel 4. Hasil Uji R-square

\begin{tabular}{|l|l|l|}
\hline & $R$-Square & $R$-Square Adjusted \\
\hline $\begin{array}{l}\text { FINANCIAL TECHNOLOGY } \\
\text { LITERACY }\end{array}$ & 0,451 & 0,444 \\
\hline
\end{tabular}

Tabel 4. menunjukkan hasil koefisien determinasi sebesar 0,451 yang berarti bahwa sebesar 45,1\% dari variabel dependen yaitu financial technology literacy dapat dijelaskan oleh variabel independen pada penelitian ini dan sisanya sebesar 54,9\% dijelaskan oleh variabelvariabel di luar penelitian ini. Nilai koefisien determinasi yang diperoleh tergolong moderat. Berdasarkan hasil perhitungan goodness of fit yang dilakukan secara manual, maka dapat disimpulkan bahwa model yang digunakan dalam penelitian ini memiliki tingkat kecocokan yang tergolong besar yaitu $0,5347(>0,36)$.

Tabel 5. Hasil Uji Hipotesis

\begin{tabular}{|c|c|c|c|}
\hline & Original Sample $(\mathrm{O})$ & $\begin{array}{l}\text { T-statistics } \\
(|\mathrm{O} / \mathrm{STDEV}|)\end{array}$ & $P$-values \\
\hline FA -> FTL & 0,323 & 5,865 & 0,000 \\
\hline FB $->$ FTL & 0,306 & 3,668 & 0,000 \\
\hline FK -> FTL & 0,205 & 2,704 & 0,007 \\
\hline
\end{tabular}

Berdasarkan hasil pengujian hipotesis didapatkan bahwa financial attitude, financial behavior, dan financial knowledge memiliki pengaruh yang positif terhadap financial technology literacy jika melihat nilai $P$-values sebesar 0 untuk FA -> FTL, sebesar 0 untuk FB -> FTL, dan 0,007 untuk FK -> FTL.

\section{DISKUSI}

Berdasarkan hasil diatas, maka dapat disimpulkan bahwa penelitian ini sudah valid dan reliabel karena telah lolos semua pengujian yang ada dengan bantuan program Smart-PLS versi 3.0. Walaupun hasil ini tidak sesuai dengan yang diharapkan, tetapi hasil penelitian ini sesuai dengan hasil penelitian dari (Agus Made \& Gede Sri Darma, 2019) yang dalam penelitiannya mendapatkan hasil bahwa literasi teknologi keuangan masyarakat Bali mengenai perkembangan teknologi berbasis pembayaran online dipengaruhi oleh sikap finansial, tingkah laku finansial, dan pengetahuan finansial. Penelitian tersebut memfokuskan produk teknologi finansial berupa pembayaran dengan menggunakan GoPay. Serta (Kamini Rai, Shikha Dua \& Miklesh Yadav, 2019) yang melakukan pengujian terhadap masyarakat India untuk mengetahui pengaruh sikap keuangan, tingkah laku keuangan, dan pengetahuan keuangan terhadap literasi teknologi keuangan namun responden yang dituju yaitu wanita yang sudah bekerja. 
Adapun juga hasil penelitian ini sesuai dengan penelitian terdahulu yaitu (Aritonang \& Arisman, 2017) yang melakukan penelitian terhadap masyarakat Palembang mengenai minat untuk menggunakan E-money atau sasaran produk teknologinya berupa penggunaan Go-Pay untuk bertransaksi. Dari penelitian ini didapatkan hasil bahwa tingkah laku finansial seperti kemudahan dan manfaat yang menjadi pemicu untuk meningkatkan literasi teknologi keuangan. Dari beberapa contoh penelitian terdahulu tersebut, maka penelitian ini membuktikan bahwa sikap keuangan, pengetahuan keuangan, dan tingkah laku keuangan memiliki pengaruh positif terhadap tujuannya untuk meningkatkan literasi teknologi keuangan.

\section{PENUTUP}

Berdasarkan hasil analisis pada uji statistik dan uji hipotesis, maka dapat disimpulkan sebagai berikut :

1. Financial attitude mempunyai pengaruh positif terhadap financial technology literacy pada pengguna Go-Pay di Jakarta Barat.

2. Financial knowledge mempunyai pengaruh positif terhadap financial technology literacy pada pengguna Go-Pay di Jakarta Barat.

3. Financial behavior mempunyai pengaruh positif terhadap financial technology literacy pada pengguna Go-Pay di Jakarta Barat.

Adapun saran untuk penelitian selanjutnya bisa menambahkan indikator untuk mendukung setiap konstruk sehingga hasil yang didapatkan bisa lebih baik daripada penelitian sebelumnya. Dan juga untuk pembahasan ruang lingkup pada penelitian dapat diperluas lagi yaitu tidak hanya terbatas pada financial technology literacy pada pengguna Go-Pay di Jakarta Barat saja, namun bisa ke seluruh DKI-Jakarta. Pembagian kuesioner bisa disebarkan lebih meluas lagi atau mungkin bisa menambah jumlah responden pada penelitian selanjutnya karena cakupan wilayah Jakarta Barat sangat luas.

\section{DAFTAR PUSTAKA}

Agus Made Krisnan Ferdiana, Gede Sri Darma. 2019. "Understanding Fintech Through Go - Pay." International Journal of Innovative Science and Research Technology 4(2):257-260.

Asli Elif Aydin, Elif Akben Selcuk, (2019) "An Investigation of Financial Literacy, Money Ethics and Time Preferences Among College Students: A Structural Equation Model", International Journal of Bank Marketing. 3(1):880-900

Jiwasiddi, C T Adhikara1, M R R Adam, I Triana. 2019. “Attitude Toward Using Fintech among Millennials." Journal of Management Department, Swiss German University.

Kamini Rai, Shikha Dua, Miklesh Yadav, 2019. "Association of Financial Attitude, Financial Behaviour and Financial Knowledge Towards Financial Literacy: A Structural Equation Modeling Approach.” FIIB Business Review 8(1):51-60.

Lia Muhibatul Aliyah, Nurdin. 2019. "Pengaruh Layanan Keuangan Berbasis Teknologi (Fintech) terhadap Literasi Keuangan Masyarakat Dago Atas, Bandung." Jurnal Manajemen, Fakultas Ekonomi dan Bisnis, Universitas Islam Bandung 5(1):649-655. 
Jefrie dan Wiyanto: Pengaruh Financial Attitude, Financial Knowledge, Dan Financial...

Luksander Alexandra, Nemeth Erzsebet, Zsoter Boglarka, 2017. "FINANCIAL PERSONALITY TYPES AND ATTITUDES THAT AFFECT FINANCIAL INDEBTEDNESS." International Journal of Social Science and Economic Research.

Nadhia Armilia, Yuyun Isbanah. 2017. "FAKTOR YANG MEMENGARUHI KEPUASAN KEUANGAN PENGGUNA FINANCIAL TECHNOLOGY DI SURABAYA.” Jurnal Ilmu Manajemen Fakultas Ekonomi Universitas Negeri Surabaya 8(1).

Yosua Arent Lonardo Aritonang, Anton Arisman. 2017. "PENGARUH PERSEPSI KEMUDAHAN DAN PERSEPSI MANFAAT TERHADAP MINAT MENGGUNAKAN E-MONEY (STUDI KASUS PADA PENGGUNA GO-PAY).” Jurnal Jurusan Akuntansi STIE Multi Data Palembang. 